Article

\title{
An Empirical Study of Renewable Energy Technology Acceptance in Ghana Using an Extended Technology Acceptance Model
}

\author{
Li Yang ${ }^{1}$, Sumaiya Bashiru Danwana ${ }^{1, *(1)}$ and Issahaku Fadilul-lah Yassaanah ${ }^{2}$ \\ 1 School of Economics and Management, Anhui University of Science and Technology, No. 168 Taifeng Road, \\ Huainan 232001, China; y321212@163.com \\ 2 School of Mathematics and Big Data, Anhui University of Science and Technology, No. 168 Taifeng Road, \\ Huainan 232001, China; issakafadil@gmail.com \\ * Correspondence: bdsumaiya@gmail.com; Tel.: +86-181-1954-9244
}

check for updates

Citation: Yang, L.; Bashiru Danwana, S.; Yassaanah, I.F.-1. An Empirical Study of Renewable Energy Technology Acceptance in Ghana Using an Extended Technology Acceptance Model. Sustainability 2021, 13, 10791. https://doi.org/10.3390/ su131910791

Academic Editors: Les Bowtell and Tony Ahfock

Received: 21 August 2021

Accepted: 24 September 2021

Published: 28 September 2021

Publisher's Note: MDPI stays neutral with regard to jurisdictional claims in published maps and institutional affiliations.

Copyright: (c) 2021 by the authors. Licensee MDPI, Basel, Switzerland. This article is an open access article distributed under the terms and conditions of the Creative Commons Attribution (CC BY) license (https:/ / creativecommons.org/licenses/by/ $4.0 /)$.
Abstract: Energy consumption, and its impact on the environment, has become an increased focal point in Ghana, a sub-Saharan African country, following population growth and rapid urbanization. Ghana has high potential for renewable energy generation; nevertheless, low acceptance and usage have been found. An extensive study is required to understand the causes driving poor acceptability and the intentions to use renewable energy. This study aims to empirically investigate the acceptance of renewable energy using an extended technology acceptance model (TAM). A cross-sectional survey was conducted, from 1 February 2021 to 30 June 2021, using a self-administered questionnaire. The survey was carried out on Ghanaian adults of the age 18 years and above. Data was collected from 1068 respondents from Ghana's northern and southern parts and analyzed using partial least squares structural equation modeling (PLS-SEM) with SmartPLS software. The results of the data analysis reveal that environmental awareness is the biggest predictor of the intention to use renewable energy in Ghana. Perceived affordability was also found to be the most significant predictor of attitudes towards the use of renewable energy in Ghana. The findings of this research will give policymakers, manufacturers, and the providers of renewable energy appliances a better understanding of the factors that determine the intention to use renewable energy.

Keywords: renewable energy; technology acceptance model (TAM); cross-sectional survey; partial least squares structural equation modeling (PLS-SEM); environmental awareness; perceived affordability

\section{Introduction}

Energy is a critical topic that has been discussed extensively throughout human existence. Access to energy is essential for improving people's living standards and for contributing to social and economic growth [1]. Many fundamental human needs are met by energy, especially fire, mechanical strength, and light. Energy research has accelerated in response to the need to reduce carbon emissions [2]. A greater percentage of the energy consumed worldwide is derived from conventional nonrenewable energy resources, such as oil, gas, and coal. These sources of energy are known to contribute to climate and environmental issues due to increased greenhouse gas emissions [3]. In addition to the high growth rate of greenhouse gas emissions, existing energy supplies are insufficient to sustain human life. Experts have forecasted the depletion of oil and gas reserves for over a century [4-6]. According to the British Petroleum Statistical Review of World Energy, reports based on proven oil reserves estimate reserves of the world's oil at 1733.9 billion barrels. In 2019, global demand was estimated to be around 35.9 billion barrels. A simple estimate shows that if proven reserves do not rise, and demand remains stable at 2019 levels, it will take about 48 years, or sometime in 2067, to deplete those reserves [7]. This information makes it crucial to use clean energy sources and identify strategies to lower $\mathrm{CO}_{2}[8]$. 
Because of the high levels of pollution and emissions caused by the use of fossil fuels, most countries have prioritized the development of cleaner energy sources, such as renewable energy [4]. Governments have incorporated effective and sustainable renewable energy generation strategies into their national energy plans $[9,10]$. For an energy policy to be viable and successful, [11] asserts that it should have two primary priorities. The first priority is to improve access to affordable, contemporary sources of energy, and the second is to identify the right balance of energy resources and services to decrease the negative environmental consequences while ensuring long-term growth. Renewable technology has grown in popularity over the past few decades as a reliable and sustainable source of energy. Renewable energy is an integral part of everyday energy use and a promising area for future energy growth [12]. Renewable energy technology will save resources, satisfy energy demand, and achieve energy sustainability [13].

Furthermore, the production of green energies will protect the atmosphere and reduce carbon emissions [14,15], which is a vital step in dealing with potential climate change. Adequate, stable, and long-term energy is the fundamental guarantor of national economic growth and social development. Moreover, it is rational to make appropriate use of renewables to achieve cost-effective and efficient energy generation.

Ghana is currently grappling with low per capita energy use and increasing demand, resulting in tensions between the energy supply and economic growth [16]. Figure 1 shows that, in 2020, the country's entire energy supply reached roughly 12,038 ktoe, representing a yearly compounded growth rate of $3.3 \%$ from 2000 to 2020 [17]. Biomass accounted for the majority of the country's overall energy supply until 2011 when oil took over as the major source of energy supply. This change was a result of the commencement of the commercial production of oil in 2011. Oil has since been the primary fuel and an essential part of the Ghanaian economy. In 2020, oil production fell by $6.3 \%$ (from 71,440 thousand barrels to 66,927 thousand barrels) from the previous year due to the COVID-19 pandemic. This decrease caused a rise in the supply of biomass over oil, accounting for nearly $36 \%$ of the overall energy supply, with oil and natural gas accounting for $34 \%$ and $25 \%$, respectively. Hydropower accounted for less than 10\% of the total energy supply from 2000 to 2020. Natural gas became part of Ghana's energy mix in 2010 and has increased consecutively from 13\% in 2017 to $25 \%$ in 2020 (Figure 1). Ghana's natural gas imports from Nigeria fell over the years when commercial gas production started in 2014. In 2020, there was a remarkable increase of $72.2 \%$ in natural gas production, from $55.3 \mathrm{tBtu}$ in 2019 to $95.2 \mathrm{tBtu}$ in 2020. Solar energy contributes the least to the energy supply, with values of less than $1 \%$ from 2016 to 2020.

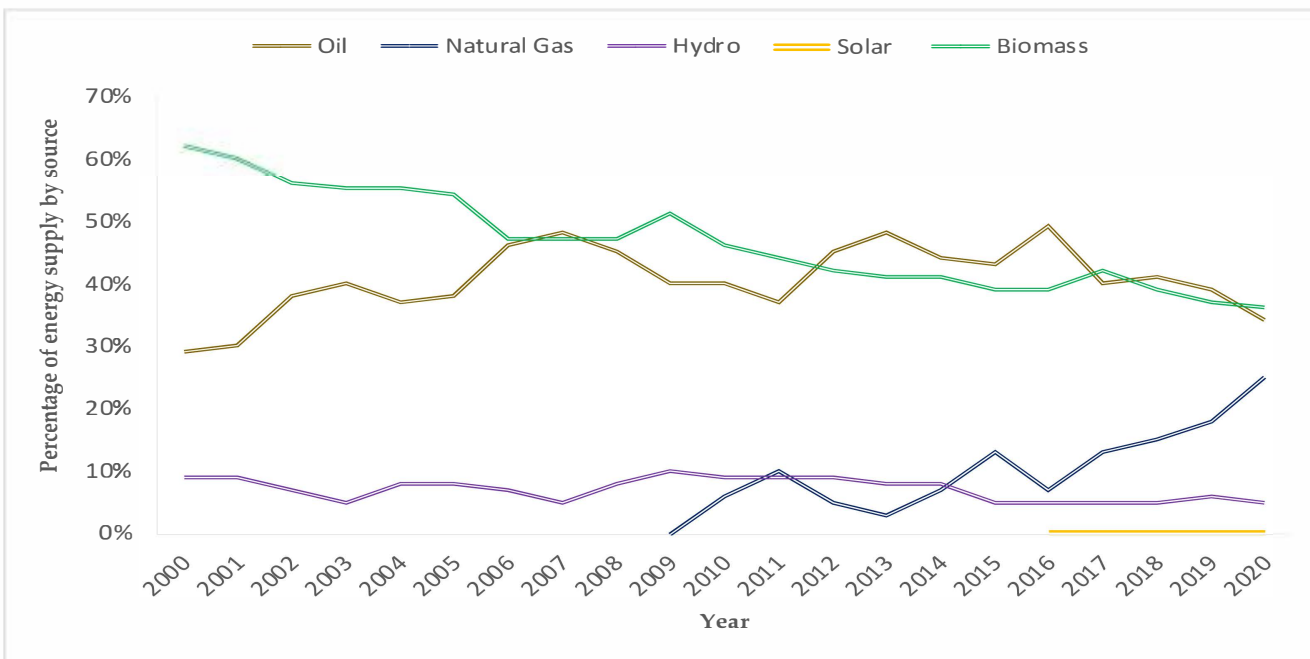

Figure 1. Ghana's total energy supply by source. 
Energy consumption data from the Ghana energy commission shows that the residential sector consumed an estimated 3477 ktoe of energy in 2020 (Figure 2). From the year 2000 to 2020, the residential sector remained the top consumer of energy. The transport sector is the next largest consumer of energy, consuming 3293 ktoe of energy in 2020. Energy consumption in the transport sector increased significantly over the years and could rise above the residential sector in the next few years. In 2019, the transport sector accounted for $37 \%$ of total energy consumed and $38 \%$ in 2020, while the residential sector's consumption fell from almost $42 \%$ in 2019 to $40 \%$ in 2020 [17]. From 2000 to 2016, the industry sector consumed less than 1000 ktoe of energy until 2017, when industry consumption rose above $1000 \mathrm{ktoe}$. The service sector, agricultural sector, and the nonenergy use sector (comprises energy products that are used as raw materials in other industries, e.g., construction materials, lubricants, and fertilizers) have the lowest consumption. These three together accounted for only $7 \%$ of the total energy consumed.

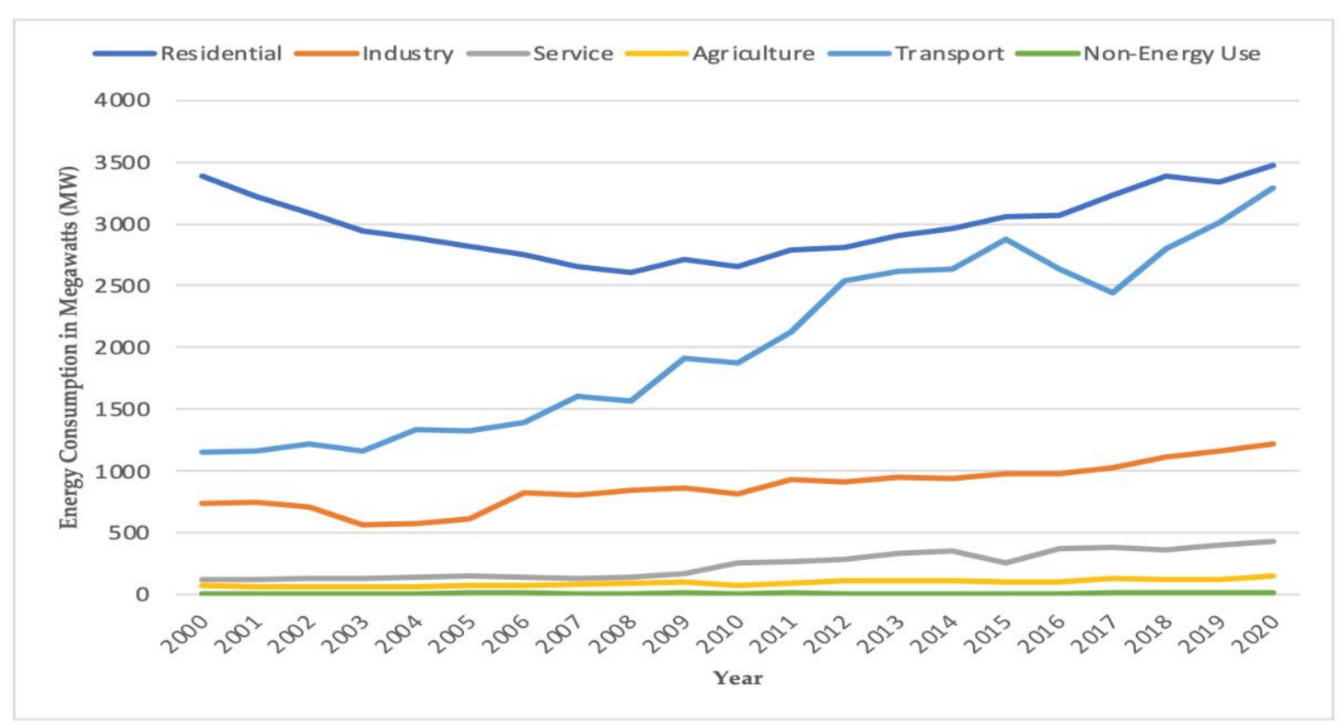

Figure 2. Energy consumption by sector (MW).

Ghana gets its power from hydroelectricity, thermal power plants powered by crude oil, natural gas and diesel, solar, and imports from Côte d'Ivoire. Ghana also exports power to Togo, Benin, and Burkina Faso [17]. The total installed capacity for existing plants in Ghana is 5288 (MW), consisting of $1580 \mathrm{MW}$ hydro, $3649 \mathrm{MW}$ thermal, and $59 \mathrm{MW}$ renewables [17]. The total power generation from these energy sources for 2020 was estimated to be 20,170 GWh (hydro $36.2 \%$; thermal $63.6 \%$; and solar less than $0.3 \%$ ). About $83 \%$ of the population has access to electricity, with $50 \%$ of the rural population, and $9 \%$ of urban inhabitants, connected to the national grid. A major obstacle to economic progress has been the lack of access to dependable power. As part of Ghana's efforts to achieve Sustainable Development Goal (SDG) 7, the government has pledged to provide universal access to electricity by $2030[15,18-20]$. There are concerns about Ghana's ability to fulfill the objective of having a dependable and sustainable electricity supply [18]. Governments have been unable to develop and implement a resilient and sustainable power infrastructure to fulfill the ever-increasing demand for electricity throughout the years. It is especially imperative for a low-middle income country like Ghana to assess population growth and increased industrialization with respect to the rise in electricity demand [18]. The power grid has been subjected to undue strain, especially because power production has been insufficient to satisfy rising demand. A comprehensive expansion of the power system is urgently needed to satisfy increasing demand while maintaining the optimal reserve margin required for the power system's secure service. In this regard, multiple generation extension projects in Ghana have been commissioned to increase generation capacity, using both traditional and renewable energy sources. 
Despite the government's numerous regulations, actions, and initiatives, the number of renewable energy installations among Ghanaians remains relatively low [15]. Public interest in renewable energy, on the other hand, is increasing, since limiting the use of fossil energy and promoting the use of renewable energy have been identified as a way to mitigate climate change. Public awareness studies [21-24] have increased awareness and the need to use renewable energy. The demand for renewable energy is rising globally, making it imperative to understand users' attitudes and intentions towards renewable energy. Several acceptance studies have been conducted using varied methods to explain users' attitudes and their intentions to use renewable energy [25-29]. Most of these studies find some level of acceptance of renewable energy. Agyekum et al. [29] found a general level of acceptance of renewable energy in Ghana, with varying acceptance levels among different individuals. Ahmad et al. [26] reveal that attitude, perceived ease of use, and perceived usefulness have a significant impact on the intention to use solar photovoltaic technology in Malaysia. Harrouz et al. [28] conducted a survey on the social acceptance of renewable energy in Algeria, and their results show a high level of acceptance. In another study conducted by Al-Fatlawi, Saidur, and Rahim [30] in Malaysia, it was found that there is a good level of acceptance of solar photovoltaic energy, even though many people did not know the benefits of using the solar photovoltaic system. Nkundabanyanga et al. [31] used ordinary least squares (OLS) to analyze the survey data of 199 households collected from two districts in Uganda. They found that the social acceptance of renewable energy in Uganda is significantly related to the perceived low vulnerability of energy systems and environmental opportunities and threats [26].

To the best of our knowledge, none of the studies on the acceptance of renewable energy have added environmental awareness and perceived affordability to the technology acceptance model (TAM) to investigate the determinants of the intention to adopt renewable energy in Ghana.

This research empirically investigates the determinants of the intention to use renewable energy in Ghana with an extension of the TAM by including environmental awareness and perceived affordability. Ref. [32] agree that the explanatory power of the technology acceptance model can be increased in a specific context by incorporating relevant variables in the model. This research will aid policymakers, renewable energy providers, and suppliers in better understanding the factors that influence the intention to adopt renewable energy in Ghana.

The rest of the paper is divided into seven sections: Section 2 discusses Ghana's renewable energy; Section 3 presents the theoretical framework and hypothesis of the research; Section 4 presents the methodology; Section 5 shows the results of the empirical analysis; Section 6 discusses the results and findings; Section 7 concludes the paper; and Section 8 states the paper's limitations.

\section{Ghana's Renewable Energy}

Ghana has significant, yet under-exploited, renewable energy sources. These include bioenergy, solar, wind, and hydropower [20]. The Ghanaian government has recognized renewable energy as one of the possibilities that can contribute to the total energy supply mix while minimizing the negative environmental consequences of energy production. As part of Sustainable Development Goals (SDG) 7 and 13 targets, Ghana released a Renewable Energy Master Plan in 2019, intending to increase Ghana's installed renewable energy generation capacity to about $2500 \mathrm{MW}$ by 2030. It is critical for Ghana to tap into the vast availability of renewable energy sources to achieve sustainable growth. Energy from renewable sources is important for energy conservation and environmental preservation. Indeed, recent renewable energy programs and initiatives have proven to have great potential in significantly reducing poverty and promoting the country's socioeconomic growth, especially in rural areas. According to Arthur et al. [33], most of the current renewable energy projects in the country are being implemented by the government as new initiatives or on a short-term basis, with low private sector participation. As a result, 
there is no obvious integrated strategy for the long-term development and promotion of the country's various renewable energy resources [33].

Renewable energy generation capacity increased from about $1656 \mathrm{MW}$ in 2019 to $1663 \mathrm{MW}$ in 2020 [34]. In 2020, 95\% of the renewable energy generated was from hydropower, and the remainder was from solar and biogas. As illustrated in Figure 3, renewable energy generation has not grown much over time, and the share of renewable energy in electricity generation has also fallen successively. The percentage of renewable energy in total electricity generation fell from $55 \%$ in 2011 to $32 \%$ in 2020 . The various sources of renewable energy in Ghana are discussed below.

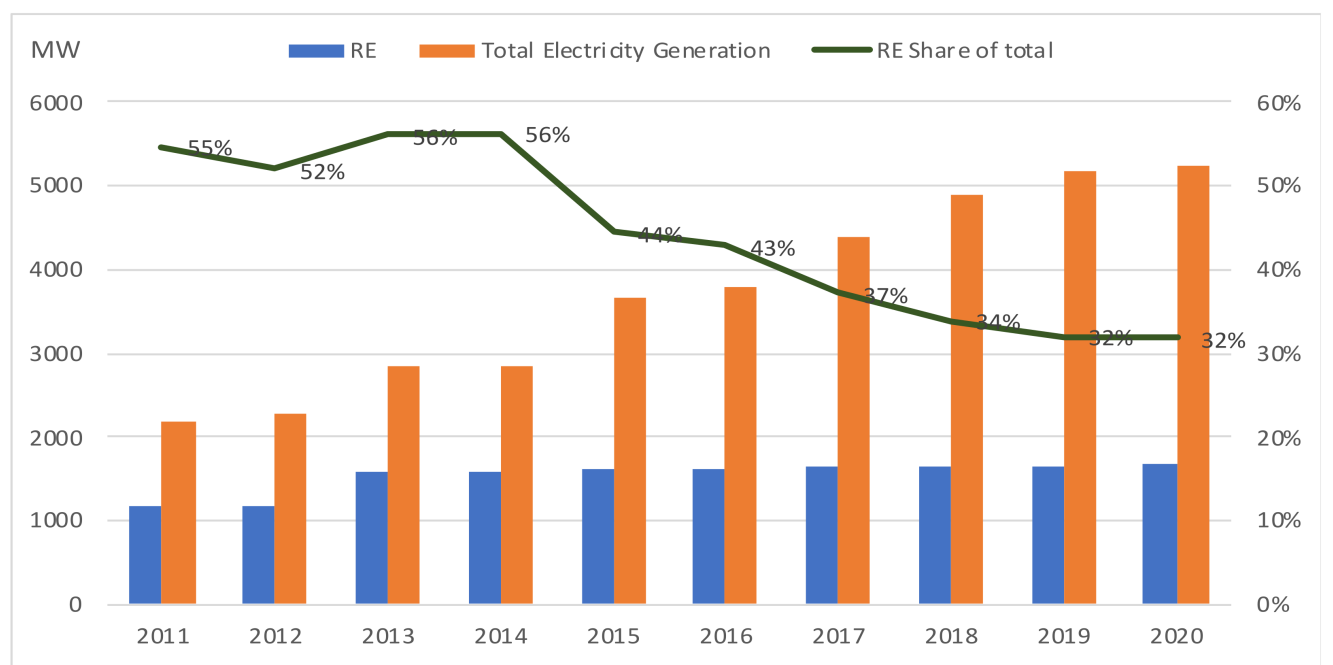

Figure 3. Ghana's renewable energy generation capacity.

- Hydropower

Hydropower has played a major part in Ghana's electricity generation. Hydropower in Ghana has an installed capacity of $1580 \mathrm{MW}$, and a dependable capacity of $1400 \mathrm{MW}$ [17]. Ghana has considerable hydropower capacity, which generated about $36.2 \%$ of the country's electricity in 2020. Because of decreasing reservoir levels, hydropower output has decreased in recent years. It is, therefore, unable to generate sufficient power to supplement thermal energy output. Thus, current energy shortages have resulted in nationwide power outages [16]. Despite the potential of big and small hydropower, hydropower generation remains underexploited.

Ghana's hydropower is generated from three large hydroelectric dams (the Akosombo, Kpong, and Bui Dams), and one recently constructed small hydroelectric dam (the Tsatsadu Generating station). While hydropower has proven to be a dependable and clean source of energy, the construction of hydroelectric power plants has created many environmental and social problems. For example, the construction of the Akosombo Dam displaced 80,000 people, increased flooding, and caused a loss of fertility in the surrounding land leading to a reduction in farming activities and aquatic habitats [35]. Since the construction of the Kpong Dam, bilharzia has been a major health issue in the region [36]. The Bui Dam project flooded Bui National Park, home of the black hippopotamus in Ghana, and made the people around the area prone to waterborne diseases due to the change in water temperature and pollution $[35,36]$.

Ghana is committed to producing more environmentally friendly hydropower and has already taken some steps to generate hydropower that does not affect biodiversity. During the construction of the Tsatsadu Generating Station (TGS), the Bui Power Authority (BPA) reported that the plant has no negative consequences on the environment. To ensure further environmental benefits, an afforestation program has been implemented, and trees 
are planted on the site of the Tsatsadu Generating Station to protect the banks of the river against siltation, sedimentation, erosion, nitrogen, and phosphate loads [37]. The afforestation program is expected to mitigate the effects of climate change and reduce the effects of hydropower generation on biodiversity.

Despite being one of the most widely used renewable energy sources in Ghana, hydropower is mostly used to supply energy to the national power grid. Because of the obvious relatively high cost of constructing and generating hydroelectricity, hydropower plants are controlled mainly by the government for transmission to the national power grid. The development of small hydropower plants for power supply in rural areas is still limited because of the dispersed settlement patterns and low economic activity in rural areas.

- Solar Energy

Solar photovoltaic (PV) tends to be the second-highest electricity output from renewable sources in Ghana, after hydropower. Because of its dependability, solar PV is becoming the most popular energy source in households, particularly for electric gadgets. Ghana has substantial solar power potential. This is due to Ghana's proximity to the equator, the enormous availability of sunshine throughout the country, and the potential growth in electricity use in rural communities that now lack a consistent electricity supply. The northern part of Ghana receives the most irradiation each year. The daily sun irradiation in Ghana is between 4 and $6 \mathrm{kWh} / \mathrm{m}^{2}$. Every year, the sun shines for 1800 to $3000 \mathrm{~h}$ on average [38-40]. According to the Ghana Energy Commission, over 38,200 off-grid solar systems, including lanterns, and 25 grid-connected solar systems, with a total installed capacity of $8 \mathrm{MW}$, have been installed in 120 communities [41].

Ghana only had 64 megawatts of solar generation capacity by the end of 2019, but by the end of 2020, the government had installed a 5-megawatt floating solar photovoltaic system on the Bui Hydroelectric Dam's reservoir. The 5-megawatt prototype photovoltaic system is the first phase of a 250-megawatt floating photovoltaic project that will be built in 50-megawatt units. The solar project was connected to the transmission system of the Chinese company Sinohydro's 404 MW Bui hydropower dam, which was completed in 2013. The Bui Power Authority (BPA), a corporation established in 2007 to run the dam, is developing the huge floating PV project [42].

Solar PV's initial cost is a key barrier to acceptance and extensive use, particularly in rural parts of the country. Because of the unreliability of the national grid in rural parts of the country, solar powered mini-grids have been installed in selected rural communities in Ghana with funding from the World Bank [43]. These mini-grids have provided these communities with economic benefits and also sustainable electricity supply systems. Solar mini-grids have a promising future for Ghana's energy sector, not just in terms of increasing access to energy, but also in terms of promoting the use of renewable energy which has a direct impact on achieving the Paris Agreement's Sustainable Development Goals (SDGs) of increasing access to cleaner sources of energy (SDG 7), and inclusive and sustainable economic growth (SDG 8). Solar energy is used chiefly for streetlights and lamps in homes. Solar energy is projected to become more widely used to satisfy the energy requirements for heating, drying farm produce, pumping systems and irrigation, and other applications.

\section{- Biomass Energy}

Biomass has been the most prevalent type of renewable energy used in developing countries and is one of Ghana's most abundant and used energy sources [20,44]. In Ghana, energy from biomass is from charcoal, firewood, and others, such as sawdust and sawmill residue [40]. Most waste products, except for firewood, are never turned into energy. Biomass energy resources constitute around 20.8 million hectares of Ghana's 23.8 million hectares of landmass, accounting for about $36 \%$ of the country's total energy consumption in 2020 [17]. Due to increased fossil fuel use, the percentage of biomass in the sources of energy in Ghana has been progressively declining [16]. According to the energy commission, the quantity of wood used for firewood has declined since 2000. A 
slight increase was seen in 2020, from 1418 ktoe to 1438 ktoe. In contrast, the wood used for charcoal production increased at an average annual growth rate of $4.8 \%$ from 2000 to 2020. In $2020,65.67 \%$ of the total wood supply was used for charcoal production, up from $28 \%$ in 2000 .

Biomass is usually generated in rural areas and offers a convenient and viable alternative to grid power. This is due to the fact that the resource is easily accessible in Ghana's rural communities. Large amounts of biomass, in the form of firewood and charcoal, are used in most rural Ghanaian households for domestic purposes, such as cooking and lighting $[16,45]$. However, in urban areas, the type of biomass needed is mostly determined by the energy conversion process and the form in which the energy is required. For example, charcoal is used as an excellent alternative to liquid petroleum gas for cooking, which in many ways offers higher outputs to replace traditional fossil-based energy sources [46]. The development and use of renewable energy and waste-to-energy resources have the prospect of ensuring Ghana's energy stability while mitigating the harmful effects of climate change. Even while biomass offers a significant quantity of energy in the long term, it causes deforestation and harms the ecology. In this context, Ghana needs to find alternative methods of producing biomass without chopping down trees.

- Wind Energy

According to Sun, Khan, and Bashir [47], Ghana is yet to connect wind energy to the national grid in an official capacity. The Ayitepa upwind farm near Accra is the only wind farm under development, with a nameplate capacity of around $225 \mathrm{MW}$ when finished. It contains 75 turbines, with a maximum height of $140 \mathrm{~m}$ [47]. Between 2002 and 2005, the United Nations Environment Program (UNEP) financed research on the potential of wind energy in Ghana. The famed US institution, the National Renewable Energy Lab (NREL), partnered with the Ghana Energy Commission and the Meteorological Service to analyze Ghana's wind power potential on and offshore. The study was called the Solar and Wind Energy Resource Assessment (SWERA). The study revealed that there is a $413 \mathrm{~km}$ square region with good-to-excellent (Class 4-6) wind resources that could sustain slightly more than $2000 \mathrm{MW}$ of wind power, and if moderate-to-excellent wind resources are added, that could increase to $5640 \mathrm{MW}$. The highest amount of energy that might be extracted from the country's available wind potential for electricity is projected to be 500-600 GWh per year [48]. According to the Ghana Energy Commission, wind energy can significantly contribute to the country's energy mix, with $10 \%$ of installed capacity and about $5 \%$ of total electricity generation potential coming from wind energy.

Pertaining to the continuing talks regarding renewable energy in Ghana, it is clear that the willingness to use renewable energy exists and that the required energy is accessible. Setting up the equipment for electricity generation for many families and businesses via solar energy, biomass, wind, or water requires careful consideration on where to place the power plants, turbines, panels, and mills. Given the high level of mismanagement and inadequate resources, financing this environmentally friendly technology and eventually providing people with power would most likely be difficult. The Ghana Energy Commission, with funding from the United Nations Environment Program (UNEP), is already conducting the initial phase of surveying different regions for different sorts of potentials for on and offshore wind energy.

\section{Theoretical Framework and Hypothesis}

Scholars have developed several models in their quest to understand the factors that influence consumers' acceptance of technology [26]. These models have been validated several times to establish their suitability for a wide range of information technology-based applications [49]. The technology acceptance model (TAM), created by Davis [50], is the most well-established and fundamental framework for technology acceptance [49]. The TAM is the most widely adopted model in technology acceptance research studies [51-54]. The TAM originated from the combination of the theory of reasoned action (TRA) and the theory of planned behavior (TPB). The TRA and the TPB are comprehensive theories of 
behavior, and the TAM extends these two theoretical predecessors to explain the factors that determine users' acceptance of a wide range of technologies [55].

The TAM, according to Ducey and Coovert [56], shows that an individual's attitude toward a type of technology or innovation, and their subsequent desire to adopt that technology, are greatly influenced by their views about the perceived usefulness and the perceived ease of use of that technology. Azjen and Gilbert Cote [57] are of the view that a person's attitude toward technology constitutes one of the biggest determining factors of that person's intention to use that technology. The TAM, in particular, uses the intention to adopt technology as a dependent variable to determine the degree to which a technology is used. The dependent variable, "intention to adopt technology", which is affected by the user's attitude toward technology, is split into two categories: perceived usefulness and perceived ease of use [58].

Perceived usefulness was initially defined by Davis, Bagozzi, and Warshaw [59] as "the extent to which a person believes that utilizing a specific system will improve work performance". Perceived ease of use, on the other hand, was defined as "the degree to which a person believes that using a particular system would be free of effort" [59]. The technology acceptance model strongly asserts that the intention of users to adopt new technology is highly dependent on the perceived ease of use of the technology [60]. According to Davis [61], perceived ease of use has a direct effect on perceived usefulness, but perceived usefulness does not affect perceived ease of use. Discussing the ease of use of renewable energy from a technological viewpoint, Bandar and Amarasena [62] argued that perceived ease of use is affected by consumers' opinions about installation, frequent usage, maintenance, and the recycling of new technology.

According to [63], attitude is the most important predictor of a person's intentions or behaviors. Fishbein and Ajzen [64] defined attitude as an individual's negative or positive feelings toward the behavior in question. The original TAM incorporates attitude as a mediator in the model according to Fishbein and Ajzen's attitude theory. In their works, Fishbein and Ajzen [64], Ducey and Coovert [56], and Verma et al. [63] have agreed that perceived usefulness and ease of use are significant predictors of attitude. The following hypotheses were developed from the original version of the TAM and are shown in Figure 4.

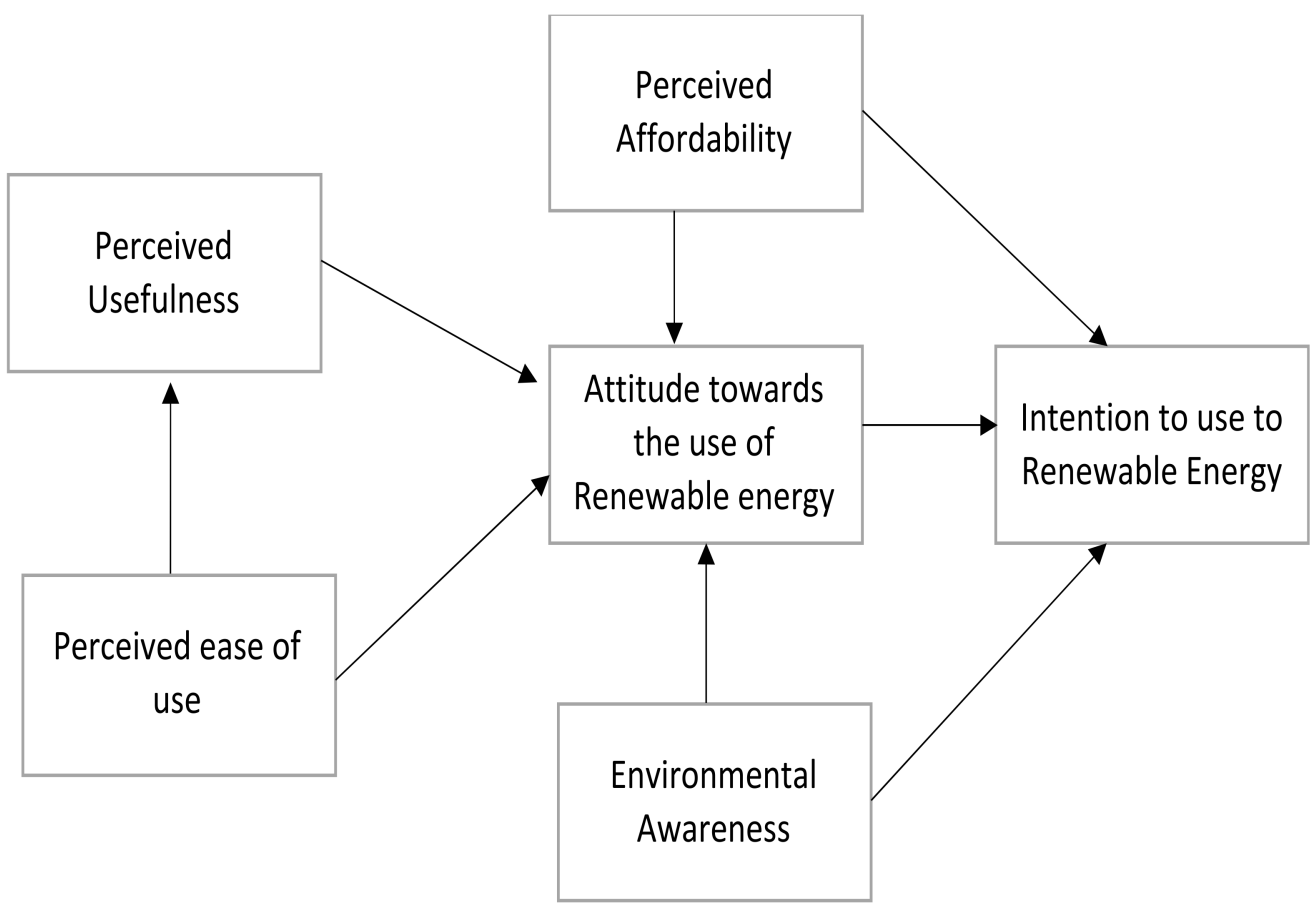

Figure 4. The framework of the study. 
H1. Attitude has a significant positive effect on the intention to use renewable energy.

H2. Perceived usefulness has a significant positive effect on attitude towards using renewable energy.

H3. Perceived ease of use has a significant positive effect on attitude towards the use of renewable energy.

H4. Perceived ease of use has a significant positive effect on the perceived usefulness of renewable energy.

\section{Extension of the TAM Model}

Numerous studies have raised concerns about using the technology acceptance model (TAM) to describe users' intentions to use new technology. Adnan et al. [65], and Verma et al. [63], have argued that the TAM may be expanded to incorporate new constructs and variables that might enhance the model and increase its explanatory power. According to King and He [66], the original TAM is an objectively basic model that may be updated or expanded in many directions, despite its empirical validity and efficacy as an important and robust predictive model for understanding and explaining varied behaviors.

The usage intention of respondents cannot be appropriately described with only a few factors in a given user scenario, such as the acceptance of renewable energy technology. The precise use of renewable energy technology is influenced by a few additional factors not included in the TAM model. This study will show how the combined effects of perceived affordability and environmental awareness can influence the acceptance of renewable energy in Ghana. Thus, the study adds perceived affordability and environmental awareness to the original variables of the TAM.

The following hypothesis was developed from the extension of the TAM. The framework of the study is shown in Figure 4.

H5. Perceived affordability has a significant positive effect on the intention to use renewable energy.

H6. Perceived affordability has a significant positive effect on the attitude towards the use of renewable energy.

H7. Environmental awareness has a significant positive effect on the intention to use renewable energy.

H8. Environmental awareness has a significant positive effect on the attitude towards the use of renewable energy.

\section{Materials and Methods}

For this study, a cross-sectional survey design using self-administered questionnaires was employed. The research was carried out between 1 February 2021, and 30 June 2021. The questionnaire included 36 questions consisting of two sections. Section One included questions about the participants' basic demographic data, such as gender, age, level of education, employment, average yearly income, and where they are in Ghana. Section Two included questions for the study model's constructs (perceived ease of use, perceived usefulness, attitude, perceived affordability, environmental awareness, and intention to use). To quantify the responses of the measured variables, a five-point Likert scale was used to collect responses on the level of agreement to the statements from between strongly disagree (1) to strongly agree (5). The questionnaire was created using a review of the available literature on technology acceptance research and renewable technology studies.

A pilot study with 80 randomly chosen Ghanaian adults was undertaken to verify the questionnaire's efficacy - questionnaires obtained from the pilot research aided in increasing its effectiveness with certain context-specific changes. The data came from a nationwide survey of Ghanaians aged 18 years and above. A random stratified sampling approach was used in the investigation. The country was divided into two sections: southern and 
northern. As a result, while choosing respondents for the survey, a proportional to size sample method was used to determine the number of respondents to be selected from each section. All participants were allowed to sign a formal consent form outlining the aim of the study, as well as assurances of confidentiality and data protection.

\section{- Data Analysis}

The data from the questionnaire were edited, coded, and entered into the computer using the Statistical Package for Social Scientists (SPSS) and Smart PLS 3.0. Data will be categorized and tabulated to address the objectives of the study. The data gathered from the survey were further evaluated using partial least squares (PLS). Because of its soft modeling assumptions, the PLS method for SEM is becoming more popular for estimating large complex models [67]. PLS-SEM is used mainly because this research seeks to uncover the key determinants of renewable energy adoption for success. While PLS-PM, as a data estimation technique, is prone to errors, it gives data-driven insights into causation and magnitudes.

Nonetheless, because PLS-SEM was used because the observations are adequate, as evidenced by their psychometric characteristics. The PLS model is made up mainly of structural and measurement models. Internal reliability and validity measurements are used to analyze the structural model. After analyzing the structural model, the PLS method uses t-testing and path values to validate the hypothesis. The PLS-SEM analysis was used to experimentally evaluate the conceptual framework and validate the hypothesized relationships between the constructs [68].

\section{Results}

Out of the 1200 questionnaires administered, 1068 were retrieved, giving a response rate of $89 \%$. Some respondents did not return the questionnaires, and a few of them returned them with inconclusive results. This resulted in the inability to add the remaining 132 questionnaires to the analysis. However, all 1068 respondents willingly filled out the questionnaire independently, or with a bit of assistance, and returned them.

\subsection{Demographic Information of Respondents}

Demographic data revealed that males outnumbered females in the research. As shown in Table 1 , the male respondents represented $52.1 \%$ of valid responses, and the females represented $46.9 \%$. We grouped the age structure because of the sensitivity around asking people their ages. We wanted to make the respondents comfortable answering this question. The age demographic showed high participation among the young people. More than $50 \%$ of respondents were in the 18-25 and 26-33 years age groups. The 26-33 years age group was represented the most, by $43.1 \%$. The results on the level of education of the respondents are competitive between master's and bachelor's degrees. More than $65 \%$ of respondents either had a master's or a bachelor's degree. Respondents who had a junior high and senior high education were only $5.1 \%$ and $12.8 \%$, respectively, and $12.7 \%$ of respondents had a PhD or higher. They were 27\% students, 25\% public servants, and $19 \%$ civil servants, and most respondents had a yearly income of from 10,001-20,000 Ghana cedis $(38 \%)$, with $43 \%$ from the northern part of Ghana, and $53 \%$ from the southern part of Ghana. 
Table 1. Demographic Data.

\begin{tabular}{cccc}
\hline & & Frequency & Percentage \\
\hline \multirow{3}{*}{ Gender } & Male & 556 & $52.1 \%$ \\
& Female & 501 & $46.9 \%$ \\
& Other & 11 & $1 \%$ \\
\hline \multirow{2}{*}{ Age } & $18-25$ & 171 & $16 \%$ \\
& $26-33$ & 460 & $43.1 \%$ \\
& $34-41$ & 235 & $22 \%$ \\
& $42-49$ & 116 & $10.9 \%$ \\
Level of Education & 50 and above & 86 & $8.1 \%$ \\
\hline \multirow{3}{*}{ Occupation } & Junior high & 54 & $5.1 \%$ \\
& Senior high & 137 & $12.8 \%$ \\
& Bachelor & 238 & $22.3 \%$ \\
& Master & 482 & $12.7 \%$ \\
\hline & PhD or higher & 136 & $9.10 \%$ \\
& Unemployed & 97 & $27.10 \%$ \\
& Student & 289 & $19 \%$ \\
& Self-employed & 203 & $25 \%$ \\
& Public Servant & 267 & $14.40 \%$ \\
& Civil servant & 154 & $5.40 \%$ \\
\hline \multirow{3}{*}{ Average Yearly Income } & Other & 58 & $26 \%$ \\
& $1000-10,000$ & 278 & $38 \%$ \\
& $10,001-20,000$ & 406 & $15 \%$ \\
& $20,001-30,000$ & 160 & $6.20 \%$ \\
& $30,001-40,000$ & 117 & $3.80 \%$ \\
\hline
\end{tabular}

\subsection{Measurement Model}

Cohen [69] recommends that, when testing for construct validity, the scale be examined using convergent, discriminant, and nomological validity tests. We used composite reliabilities, Dijkstra-Henseler's rho (RhoA) and Cronbach's alpha, to measure reliability. Composite reliability measures the internal consistency of the items on the scale. The results in Table 2 show that the composite reliability, RhoA, and the Cronbach's alpha values are above 0.7 . This means that all of the constructs in this study's measurement items are accurate $[70,71]$. The same table also indicates that all average variance extracted values for all constructs are greater than 0.50 . The resulting factor loading for each construct passes the minimum prerequisite requirement of 0.7 for the convergent validity test to pass [68].

Table 2. Construct Reliability and Validity.

\begin{tabular}{|c|c|c|c|c|c|}
\hline & Loadings & $\begin{array}{c}\text { Cronbach's } \\
\text { Alpha }\end{array}$ & RhoA & $\begin{array}{l}\text { Composite } \\
\text { Reliability }\end{array}$ & $\begin{array}{c}\text { Average Variance } \\
\text { Extracted (AVE) }\end{array}$ \\
\hline ATT & $\begin{array}{l}0.778 \\
0.780 \\
0.757 \\
0.807 \\
0.819\end{array}$ & 0.848 & 0.849 & 0.891 & 0.622 \\
\hline EW & $\begin{array}{l}0.733 \\
0.798 \\
0.820 \\
0.853 \\
0.794\end{array}$ & 0.860 & 0.864 & 0.899 & 0.641 \\
\hline
\end{tabular}


Table 2. Cont.

\begin{tabular}{|c|c|c|c|c|c|}
\hline & Loadings & $\begin{array}{c}\text { Cronbach's } \\
\text { Alpha }\end{array}$ & RhoA & $\begin{array}{l}\text { Composite } \\
\text { Reliability }\end{array}$ & $\begin{array}{l}\text { Average Variance } \\
\text { Extracted (AVE) }\end{array}$ \\
\hline IU & $\begin{array}{l}0.726 \\
0.749 \\
0.768 \\
0.802 \\
0.790\end{array}$ & 0.825 & 0.825 & 0.877 & 0.589 \\
\hline PA & $\begin{array}{l}0.726 \\
0.749 \\
0.768 \\
0.802 \\
0.790\end{array}$ & 0.820 & 0.823 & 0.874 & 0.582 \\
\hline PEOU & $\begin{array}{l}0.792 \\
0.802 \\
0.779 \\
0.839 \\
0.768\end{array}$ & 0.856 & 0.857 & 0.897 & 0.634 \\
\hline PU & $\begin{array}{l}0.788 \\
0.827 \\
0.844 \\
0.820 \\
0.680\end{array}$ & 0.852 & 0.853 & 0.895 & 0.631 \\
\hline
\end{tabular}

We also tested for discriminant validity to check if the measurements that are not anticipated to be related are, in fact, unrelated. The results of the discriminant validity test are shown in Table 3. The square root of the average variance extracted for each construct should be greater than its highest correlation with any other construct, according to the Fornell-Larcker criterion [72-75].

Table 3. Discriminant Validity.

\begin{tabular}{ccccccc}
\hline & ATT & EW & IU & PA & PEOU & PU \\
\hline ATT & 0.789 & & & & & \\
EW & 0.680 & 0.801 & & & & \\
IU & 0.710 & 0.740 & 0.768 & & & \\
PA & 0.675 & 0.712 & 0.584 & 0.763 & & \\
PEOU & 0.523 & 0.770 & 0.464 & 0.746 & 0.796 & \\
PU & 0.674 & 0.655 & 0.717 & 0.730 & 0.697 & 0.794 \\
\hline
\end{tabular}

ATT = attitude; EW = environmental awareness; IU = intention to use; PA = perceived affordability; PEOU = perceived ease of use; $\mathrm{PU}=$ perceived usefulness.

\subsection{Structural Model}

Relationships were evaluated in the structural model (Figure 5) using Smart PLS 3.0. The model used for this study had three endogenous variables and three exogenous variables. The values of the $\mathrm{R}^{2}$ (coefficient of determination) and path coefficients were to draw the statistical inference. Validation of the data for the hypothesized model is enhanced by the values of $\mathrm{R}^{2}$ and the path coefficient. The structural model helps to determine the relationship between unobserved constructs [76]. 


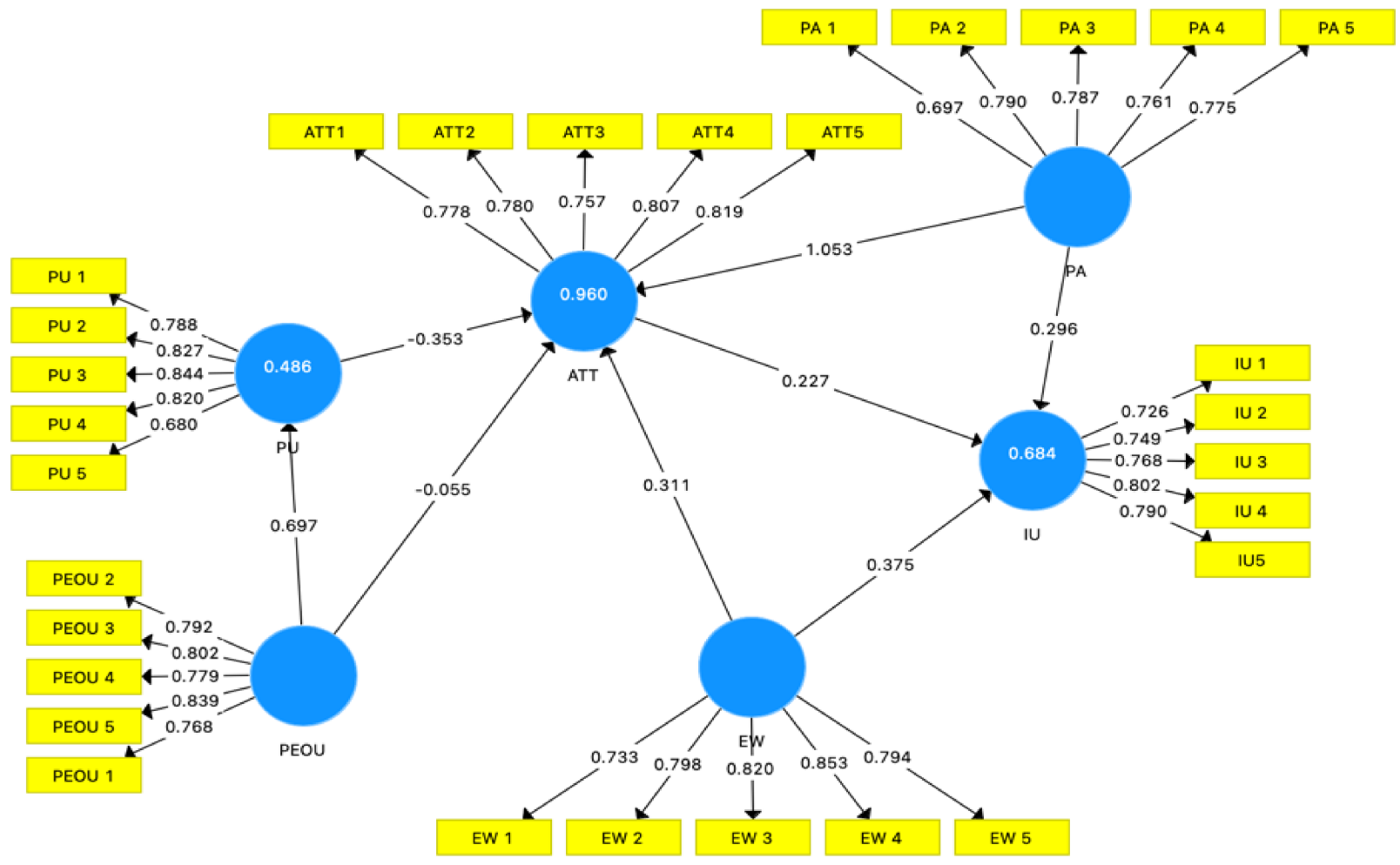

Figure 5. Structural Model.

The output generated by the structural model for the correlations between the constructs of the hypothesized model are presented in Table 4 and Figure 5, with the values of all path coefficients and $R^{2}$. The results imply a significant positive effect of all the factors toward the intention to use renewable energy. All the hypotheses are accepted and have a high level of statistical significance. Attitude has a positive significant influence on the intention to use renewable energy (H1: $\beta=0.227, p=0.016)$. PU and PEOU have a positive significant effect on ATT (H2: $\beta=0.353, p=0.000$ : H3: $\beta=0.055, p=0.000)$, PEOU has an effect on PU (H4: $\beta=0.697, p=0.000$ ), while PA has a positive and significant influence on IU (H5: $\beta=0.296, p=0.002$ : H6: $\beta=1.053, p=0.000$ ). At the same time, EW had a positive influence on ATT and IU as well (H7: $\beta=0.375, p=0.000$ : H8: $\beta=0.311, p=0.000$ ). The results also reveal that attitude towards the use of renewable energy, environmental awareness, and perceived affordability accounted for $68 \%$ of the variance in the intention to use renewable energy. The combined effect of perceived usefulness, perceived ease of use, environmental awareness, and perceived affordability explains the $96 \%$ variance in attitude towards the use of renewable energy, and $49 \%$ of the variance in PU was explained by PEOU.

Table 4. Hypothesis Testing.

\begin{tabular}{|c|c|c|c|c|c|}
\hline Hypothesis & Paths & $\begin{array}{c}\text { Path } \\
\text { Coefficients }(\beta)\end{array}$ & T Statistics & Probability Values & Status \\
\hline H1 & $\mathrm{ATT} \Rightarrow \mathrm{IU}$ & 0.227 & 2.424 & 0.016 & Accepted \\
\hline $\mathrm{H} 2$ & $\mathrm{PU} \Rightarrow \mathrm{ATT}$ & 0.353 & 13.630 & 0.000 & Accepted \\
\hline $\mathrm{H} 3$ & $\mathrm{PEOU} \Rightarrow \mathrm{ATT}$ & 0.055 & 3.997 & 0.000 & Accepted \\
\hline $\mathrm{H} 4$ & $\mathrm{PEOU} \Rightarrow \mathrm{PU}$ & 0.697 & 19.631 & 0.000 & Accepted \\
\hline H5 & $\mathrm{PA} \Rightarrow \mathrm{IU}$ & 0.296 & 3.149 & 0.002 & Accepted \\
\hline H6 & $\mathrm{PA} \Rightarrow \mathrm{ATT}$ & 1.053 & 18.275 & 0.000 & Accepted \\
\hline $\mathrm{H} 7$ & $\mathrm{EW} \Rightarrow \mathrm{IU}$ & 0.375 & 14.555 & 0.000 & Accepted \\
\hline $\mathrm{H} 8$ & $\mathrm{EW} \Rightarrow \mathrm{ATT}$ & 0.311 & 10.802 & 0.000 & Accepted \\
\hline
\end{tabular}

$\mathrm{ATT}=$ attitude; $\mathrm{EW}=$ environmental awareness; IU = intention to use; PA = perceived affordability; PEOU = perceived ease of use; $\mathrm{PU}=$ perceived usefulness. 


\subsection{The Effect Size}

The effect size $[77,78]$ is a measure of the intensity of the relationship between variables that is independent of the sample size. Cohen's $\mathrm{f}^{2}$ coefficient is the most used $[77,78]$. Effect sizes of $0.02,0.15$, and 0.35 are referred to as modest, medium, and big, respectively [78]. Values below 0.02 have no effect size. Table 5 shows that ATT (0.108) and PA (0.112) have small effects on IU, while EW (0.218) has medium effects on IU. EW (0.156) and PU (0.299) all have medium effects on ATT. Furthermore, PEOU has small effects on ATT and large effects on PU.

Table 5. Effect Size $F^{2}$.

\begin{tabular}{cccc}
\hline & ATT & IU & PU \\
\hline ATT & & 0.108 & \\
EW & 0.156 & 0.218 & \\
PA & 0.511 & 0.112 & 0.945 \\
PEOU & 0.022 & & \\
PU & 0.229 & & \\
\hline
\end{tabular}

\subsection{Predictive Relevance}

$\mathrm{Q}^{2}$ demonstrates how effectively empirical data can be recreated using the model and PLS parameters [79]. According to Akter et al. [67], predictive relevance is essential for determining how effectively the model reproduces observed values. The formula for calculating predictive relevance is:

$$
\mathrm{Q}^{2}=\left(1-\frac{\mathrm{SSE}}{\mathrm{SSO}}\right)
$$

where SSE $=$ Sum of the Squared Prediction Errors and SSO = Sum of Squared Observations.

We calculated the predictive relevance of the model using the blindfolding procedure on SmartPLS 3.0. If the value of $\mathrm{Q}^{2}$ is less than zero, it means the model is very poor, and all dependent variables cannot explain the independent variable. According to Chin [80], the predictive values of $0.02,0.15$, and 0.35 have small, medium, and large predictive relevance, respectively. Table 6 shows that the Q2 values for ATT (0.592) and IU (0.398) have a large predictive relevance, while the PU (0.297) has a medium predictive relevance. As a result, the model's predictive significance is confirmed because the $Q^{2}$ values of all endogenous constructs are greater than zero.

Table 6. Predictive Relevance.

\begin{tabular}{cc}
\hline & $\mathbf{Q}^{2}$ \\
\hline ATT & 0.592 \\
IU & 0.398 \\
PU & 0.297 \\
\hline
\end{tabular}

\section{Discussion}

This study was carried out within a theoretical framework based on the technology acceptance model (TAM). We accept $\mathrm{H} 1$ because we found a significant relationship between attitude and intention to use renewable energy. This suggests that the attitude of Ghanaians towards renewable energy is influenced by their intentions. This conclusion is consistent with the findings of other TAM-related research [63,81]. In a similar context, Rezaei and Ghofranfarid [82] state that people who have a positive attitude toward new technology have a psychological readiness for it and are better equipped to respond favorably to it. This psychological readiness may influence the intention to use technology. According to psychology theory, the elements of attitude, which include effect, cognition, and behavior, lead to a positive response in people's desire to use technology [81]. Furthermore, several 
researchers have confirmed that attitude is a reliable predictor of behavior throughout the early phases of technology adoption [83]. As a result, knowing the attitude of Ghanaians towards the use of renewable energy is crucial because all programs and policies connected to the deployment and promotion of renewable energy technology would be futile if the role of attitude were not considered.

As predicted, two of the original TAM's core constructs (perceived usefulness and perceived ease of use) have positive and significant relationships with attitude (H2 and H3). These findings indicate that the positive attitude of Ghanaians towards renewable energy is due to the ease of use and the benefits of using renewable energy. Cheung and Vogel [83], Ahmad et al. [26], and Verma et al. [63] achieved similar results, indicating that the more helpful renewable energy is, the more favorable users' attitudes will be. According to Gefen and Straub [84], perceived usefulness is a reaction to user assessment in its extrinsic, i.e., task-oriented outcomes and goals, such as task efficiency and effectiveness. In such cases, if consumers are aware of the benefits of using renewable energy, they are more likely to have a positive attitude toward it. Khazaei Pool et al. [85], and Ahmad et al. [26], pointed out that improved perceived ease of use might lead to a more positive attitude toward technology implementation. More precisely, perceived ease of use is associated with the nature of the job [84] and the fundamental characteristics of technology, such as simplicity of use, clarity, and adaptability [86]. As people learn how to use technology and become more familiar with it, they are more likely to have positive views about it [87]. The significance of $\mathrm{H} 2$ and $\mathrm{H} 3$ makes it important to take appropriate actions to encourage the creation of positive attitudes regarding renewable energy technology among Ghanaians.

Consistent with previous research [88,89], the perceived ease of use was found to have a substantial positive influence on the perceived usefulness of renewable energy (supporting H4). This finding suggests that if renewable energy technology can be used without difficulty, Ghanaians will regard it as more helpful. Venkatesh and Davis [58] suggest that the less effort required to use a system, the greater the gain in work performance attained by using it. Additionally, Yi et al. [88] revealed that a reduction in effort is a significant component in the usefulness that a person receives from adopting innovations or technology. In other words, innovation with a challenging application is unlikely to be viewed as helpful [89]. Individuals who find it easy to use technology will appreciate its use and be willing to put it to use [89]. In the current study area, when Ghanaians are dealing with clear and easy-to-use renewable energy devices, they tend to identify and acknowledge the renewable energy device's qualities that make it more beneficial. As a result, perceived ease of use is critical in encouraging the adoption of any technology, including renewable energy, and promoting a more significant feeling of usefulness.

The results of this study indicated that $\mathrm{H} 5$ and $\mathrm{H} 6$ were supported in the extended TAM in the sense that perceived affordability had significant positive effects on the attitude towards the use of renewable energy and the intention to use renewable energy.

Furthermore, environmental awareness was found to have a statistically significant relationship with both intention and attitude, supporting H7 and H8. In general, the use of renewable energy requires the user to have some level of conscience about protecting the environment. This is consistent with the findings of $[90,91]$. Karasmanaki and Tsantopoulos stated that students were in favor of renewables because of their environmental concerns and enhanced environmental awareness in general. In a similar context, Karaoğlan and Durukan added that an environmentally conscious user would choose environmentally friendly products not just in energy use, but in different categories. Hence, as people become more environmentally conscious, their desire to save energy increases. Therefore, those with a higher level of environmental awareness would have a higher intention to use renewable energy.

\section{Conclusions}

This study developed an extended TAM model to investigate users' intentions to use renewable energy among Ghanaians. This research model explains $68 \%$ of the variance in the intention to use renewable energy. According to the research findings, factors like 
perceived usefulness, perceived ease of use, environmental awareness, and perceived affordability positively affect attitudes toward the use of renewable energy. The results of the study also show that environmental awareness, perceived affordability, and attitude toward the use of renewable energy have a positive and significant effect on users' intention to use renewable energy.

The data analysis interpreted by SmartPLS shows that environmental awareness is the most important determinant of the intention to use renewable energy in Ghana. Perceived affordability is an important determinant of the attitudes towards the use of renewable energy in Ghana. This is a good sign for future endeavors in green energy. Existing research aids in explaining and comprehending user attitudes toward the adoption and use of renewable energy. Because attitudes toward the use of technology are highly dependent on a variety of variables, the suggested model provides basic information for the improvement and comprehension of renewable energy use intentions.

The study's findings give in-depth knowledge and valuable guidelines that will assist the government of Ghana, and other organizations, in their efforts to promote the use of renewable energy. The analysis has shown that environmental awareness is a critical factor in determining the acceptance of renewable energy in Ghana. Ghanaians with a high level of environmental awareness are more likely to use renewable energy. The promotion of environmental awareness campaigns and education on climate change will go a long way in promoting the use of renewable energy in Ghana.

Prospects for using renewable energy resources to their full potential in the next decade are high. With the current renewable energy plan, Ghana will achieve reduced air pollution, increase energy diversity, and reduce the use of fossil fuels by 2030. This will, in effect, create eco-friendly jobs and promote sustainable development.

\section{Limitations}

This paper is limited in the mode of analysis. Like many other types of research, this paper has numerous limitations that should be acknowledged. To begin with, because this study was done in a developing sub-Saharan African country, the findings may not accurately represent the intention to use renewable energy in other countries and continents. Thus, researchers should exercise caution when generalizing the findings.

It is also important to note that the findings in this article are based on data collected from a small sample of the population and are, thus, susceptible to error. Despite our assurances that responses would be kept confidential, some respondents may have submitted responses that would portray them in a positive light. We suspect that a level of social desirability bias seeped into the statistics on education levels due to the prestige attached to higher levels of education in Ghana, resulting in a higher percentage of high levels of education than the national demographic.

Furthermore, although the variables used in this study were able to account for a significant portion of the variance in the intention to use renewable energy in Ghana, there are still many other factors that could have been added to this analysis. Future research can add more factors using different models with mediating and moderating variables to explain the intention to use renewable energy. Finally, because this study used a crosssectional design that collects data at a particular time, future studies may explore using a longitudinal design that accounts for temporal differences.

Author Contributions: Conceptualization, S.B.D.; Data curation, I.F.-1.Y.; Formal analysis, I.F.-1.Y.; Funding acquisition, L.Y.; Methodology, S.B.D. and I.F.-1.Y.; Project administration, S.B.D.; Resources, L.Y.; Supervision, L.Y.; Writing—original draft, S.B.D.; Writing—review \& editing, L.Y., S.B.D. and I.F.-1.Y. All authors have read and agreed to the published version of the manuscript.

Funding: This research was supported by the National Natural Science Foundation of China under the grant (No. 71971003).

Institutional Review Board Statement: Not Applicable.

Informed Consent Statement: Not applicable. 
Conflicts of Interest: The authors declare no conflict of interest.

\section{References}

1. Atuguba, R.A.; Tuokuu, F.X.D. Ghana's Renewable Energy Agenda: Legislative Drafting in Search of Policy Paralysis. Energy Res. Soc. Sci. 2020, 64, 101453. [CrossRef]

2. Kwakwa, P.A. What Determines Renewable Energy Consumption? Startling Evidence from Ghana. Int. J. Energy Sect. Manag. 2021, 15, 108-118. [CrossRef]

3. Sharvini, S.R.; Noor, Z.Z.; Chong, C.S.; Stringer, L.C.; Yusuf, R.O. Energy Consumption Trends and Their Linkages with Renewable Energy Policies in East and Southeast Asian Countries: Challenges and Opportunities. Sustain. Environ. Res. 2018, 28, 257-266. [CrossRef]

4. Moriarty, P.; Honnery, D. Can Renewable Energy Power the Future? Energy Policy 2016, 93, 3-7. [CrossRef]

5. Momete, D.C. Analysis of the Potential of Clean Energy Deployment in the European Union. IEEE Access 2018, 6, 54811-54822. [CrossRef]

6. Kirsch, S. Running out? Rethinking Resource Depletion. Extr. Ind. Soc. 2020, 7, 838-840. [CrossRef] [PubMed]

7. Ersoy, E.; Schaffer, M.E.; Ditzen, J. BP Full Report—BP Statistical Review of World Energy 2019; BP: London, UK, 2019.

8. Behrouzi, F.; Nakisa, M.; Maimun, A.; Ahmed, Y.M. Global Renewable Energy and Its Potential in Malaysia: A Review of Hydrokinetic Turbine Technology. Renew. Sustain. Energy Rev. 2016, 62, 55-74. [CrossRef]

9. Visschers, V.H.M.; Siegrist, M. Find the Differences and the Similarities: Relating Perceived Benefits, Perceived Costs and Protected Values to Acceptance of Five Energy Technologies. J. Environ. Psychol. 2014, 40, 117-130. [CrossRef]

10. Dagoumas, A.S.; Koltsaklis, N.E. Review of Models for Integrating Renewable Energy in the Generation Expansion Planning. Appl. Energy 2019, 242, 1573-1587. [CrossRef]

11. Michael, A.; Wisdom, A.; Ebenezer, A. Technical and Socio-Economic Issues of Small-Scale Solar PV Electricity Supply in Rural Ghana. Energy Power 2017, 7, 10-21.

12. Shahnazi, R.; Dehghan Shabani, Z. Do Renewable Energy Production Spillovers Matter in the EU? Renew. Energy 2020, 150, 786-796. [CrossRef]

13. Asif, M. Urban Scale Application of Solar PV to Improve Sustainability in the Building and the Energy Sectors of KSA. Sustainability 2016, 8, 1127. [CrossRef]

14. Bhowmik, C.; Bhowmik, S.; Ray, A.; Pandey, K.M. Optimal Green Energy Planning for Sustainable Development: A Review. Renew. Sustain. Energy Rev. 2017, 71, 796-813. [CrossRef]

15. Mahama, M.; Derkyi, N.S.A.; Nwabue, C.M. Challenges of Renewable Energy Development and Deployment in Ghana: Perspectives from Developers. GeoJournal 2021, 86, 1425-1439. [CrossRef]

16. Kuamoah, C. Renewable Energy Deployment in Ghana: The Hype, Hope and Reality. Insight Afr. 2020, 12, 45-64. [CrossRef]

17. Energy Commission. National Energy Statistics 2020 Edition; Energy Commission: Accra, Ghana, 2021 ; ISBN 0302813764.

18. Eshun, M.E.; Amoako-Tuffour, J. A Review of the Trends in Ghana's Power Sector. Energy Sustain. Soc. 2016, 6, 9. [CrossRef]

19. Aboagye, B.; Gyamfi, S.; Ofosu, E.A.; Djordjevic, S. Status of Renewable Energy Resources for Electricity Supply in Ghana. Sci. Afr. 2021, 11, e00660. [CrossRef]

20. Acheampong, M.; Yu, Q.; Ertem, F.C.; Ebude, L.D.E.; Tanim, S.; Eduful, M.; Vaziri, M.; Ananga, E. Is Ghana Ready to Attain Sustainable Development Goal (SDG) Number 7?-A Comprehensive Assessment of Its Renewable Energy Potential and Pitfalls. Energies 2019, 12, 408. [CrossRef]

21. Ribeiro, F.; Ferreira, P.; Araújo, M.; Braga, A.C. Public Opinion on Renewable Energy Technologies in Portugal. Energy 2014, 69, 39-50. [CrossRef]

22. Ediger, V.Ş.; Kirkil, G.; Çelebi, E.; Ucal, M.; Kentmen-Çin, Ç. Turkish Public Preferences for Energy. Energy Policy 2018, 120, 492-502. [CrossRef]

23. Kim, J.; Jeong, D.; Choi, D.; Park, E. Exploring Public Perceptions of Renewable Energy: Evidence from a Word Network Model in Social Network Services. Energy Strategy Rev. 2020, 32, 100552. [CrossRef]

24. Albattah, M.; Attoye, D.E. A Quantitative Investigation on Awareness of Renewable Energy Building Technology in the United Arab Emirates. Sustainability 2021, 13, 6665. [CrossRef]

25. Feng, H.Y. Key Factors Influencing Users' Intentions of Adopting Renewable Energy Technologies. Acad. Res. Int. 2012, 2, 156-168.

26. Ahmad, S.; bin Mat Tahar, R.; Cheng, J.K.; Yao, L. Public Acceptance of Residential Solar Photovoltaic Technology in Malaysia PSU Res. Rev. 2017, 1, 242-254. [CrossRef]

27. Zaharim, A.; Mat, S.; Sopian, K.; Jedi, A.; Zaharim, A.; Safari, M.A.M.; Masseran, N.; Rahim, A.B.A. Public Acceptance on Stand-Alone Renewable Energy Project in Rural Area of Malaysia. In Proceedings of the 2017 International Conference in Energy and Sustainability in Small Developing Economies (ES2DE), Funchal, Portugal, 10-12 July 2017; IEEE: Funchal, Portugal, 2017.

28. Harrouz, A.; Belatrache, D.; Boulal, K.; Colak, I.; Kayisli, K. Social Acceptance of Renewable Energy Dedicated to Electric Production. In Proceedings of the 2020 9th International Conference on Renewable Energy Research and Application (ICRERA), Glasgow, UK, 27-30 September 2020.

29. Agyekum, E.B.; Ali, E.B.; Kumar, N.M. Clean Energies for Ghana-An Empirical Study on the Level of Social Acceptance of Renewable Energy Development and Utilization. Sustainability 2021, 13, 3114. [CrossRef] 
30. Al-Fatlawi, A.W.A.; Saidur, R.; Rahim, N.A. Researching Social Acceptability of Renewable-Energy Technology in Malaysia. In Proceedings of the 3rd IET International Conference on Clean Energy and Technology (CEAT), Kuching, Malaysia, 24-26 November 2014. [CrossRef]

31. Nkundabanyanga, S.K.; Muhwezi, M.; Musimenta, D.; Nuwasiima, S.; Najjemba, G.M. Exploring the Link between Vulnerability of Energy Systems and Social Acceptance of Renewable Energy in Two Selected Districts of Uganda. Int. J. Energy Sect. Manag. 2020, 14, 1089-1122. [CrossRef]

32. Gbongli, K.; Xu, Y.; Amedjonekou, K.M. Extended Technology Acceptance Model to Predict Mobile-Based Money Acceptance and Sustainability: A Multi-Analytical Structural Equation Modeling and Neural Network Approach. Sustainability 2019, 11, 3639. [CrossRef]

33. Arthur, R.; Baidoo, M.F.; Osei, G.; Boamah, L.; Kwofie, S. Evaluation of Potential Feedstocks for Sustainable Biogas Production in Ghana: Quantification, Energy Generation, and $\mathrm{CO}_{2}$ Abatement. Cogent Environ. Sci. 2020, 6, 1868162. [CrossRef]

34. IRENA. Renewable Capacity Statistics 2021; IRENA: Abu Dhabi, United Arab Emirates, 2021.

35. Darko, D.; Kpessa-Whyte, M.; Obuobie, E.; Siakwah, P.; Torto, O.; Tsikata, D. The Context and Politics of Decision Making on Large Dams in Ghana: An Overview; FutureDAMS Working Paper: Manchester, UK, 2019.

36. Shirazu Alhassan, H. Viewpoint-Butterflies vs. Hydropower: Reflections on Large Dams in Contemporary Africa. Water Altern. 2009, 2, 148-160.

37. $45 \mathrm{~kW}$ Tsatsadu Generating Station. Available online: https://buipower.com/tsatsadu-generating-station/ (accessed on 14 September 2021).

38. Energy Commission. Annual Report for 2011; State Enterprises Audit Corporation: Accra, Ghana, 2011.

39. Asumadu-Sarkodie, S.; Owusu, P.A. A Review of Ghana's Solar Energy Potential. AIMS Energy 2016, 4, 675-696. [CrossRef]

40. Akom, K.; Shongwe, T.; Joseph, M.K.; Padmanaban, S. Energy Framework and Policy Direction Guidelines: Ghana 2017-2050 Perspectives. IEEE Access 2020, 8, 152851-152869. [CrossRef]

41. Gyamfi, S.; Modjinou, M.; Djordjevic, S. Improving Electricity Supply Security in Ghana-The Potential of Renewable Energy. Renew. Sustain. Energy Rev. 2015, 43, 1035-1045. [CrossRef]

42. PV Magazine On-Going Initiatives to Accelerate Sustainable Uptake of Renewable Energy. Available online: https:/ /www.pvmagazine.com/2020/12/15/first-unit-of-250-mw-floating-pv-project-comes-online-in-ghana/ (accessed on 18 August 2021).

43. Bukari, D.; Kemausuor, F.; Quansah, D.A.; Adaramola, M.S. Towards Accelerating the Deployment of Decentralised Renewable Energy Mini-Grids in Ghana: Review and Analysis of Barriers. Renew. Sustain. Energy Rev. 2021, 135, 110408. [CrossRef]

44. Merem, E.C.; Twumasi, Y.; Wesley, J.; Isokpehi, P.; Fageir, S.; Crisler, M.; Romorno, C.; Hines, A.; Ochai, G.S.; Leggett, S.; et al. Assessing Renewable Energy Use in Ghana: The Case of the Electricity Sector. Energy Power 2018, 8, 16-34. [CrossRef]

45. Karakara, A.-W.A.; Dasmani, I. An Econometric Analysis of Domestic Fuel Consumption in Ghana: Implications for Poverty Reduction. Cogent Soc. Sci. 2019, 5, 1697499. [CrossRef]

46. Karekezi, S.; Afrepen, W.K. Renewable Energy Development. In Proceedings of the The Workshop for African Energy Experts on Operationalizing the NEPAD energy Initiative, Dakar, Senegal, 2-4 June 2003.

47. Sun, H.; Khan, A.R.; Bashir, A.; Alemzero, D.A.; Abbas, Q.; Abudu, H. Energy Insecurity, Pollution Mitigation, and Renewable Energy Integration: Prospective of Wind Energy in Ghana. Environ. Sci. Pollut. Res. 2020, 27, 38259-38275. [CrossRef] [PubMed]

48. Opam, M. On-Going Initiatives to Accelerate Sustainable Uptake of Renewable Energy; Energy Commision: Accra, Ghana, 2015.

49. Carter, L.; Bélanger, F. The Utilization of E-Government Services: Citizen Trust, Innovation and Acceptance Factors. Inf. Syst. J. 2005, 15, 11-20. [CrossRef]

50. Davis, F.D. Perceived Usefulness, Perceived Ease of Use, and User Acceptance of Information Technology. MIS Q. 1989, 13, 318-340. [CrossRef]

51. Okazaki, S. What Do We Know about Mobile Internet Adopters? A Cluster Analysis. Inf. Manag. 2006, 43, 127-141. [CrossRef]

52. Mital, M.; Chang, V.; Choudhary, P.; Papa, A.; Pani, A.K. Adoption of Internet of Things in India: A Test of Competing Models Using a Structured Equation Modeling Approach. Technol. Forecast. Soc. Chang. 2018, 136, 339-346. [CrossRef]

53. Pal, D.; Funilkul, S.; Charoenkitkarn, N.; Kanthamanon, P. Internet-of-Things and Smart Homes for Elderly Healthcare: An End User Perspective. IEEE Access 2018, 6, 10483-10496. [CrossRef]

54. Rafique, H.; Anwer, F.; Shamim, A.; Minaei-Bidgoli, B.; Qureshi, M.A.; Shamshirband, S. Factors Affecting Acceptance of Mobile Library Applications: Structural Equation Model. Libri 2018, 68, 99-112. [CrossRef]

55. Park, N.; Rhoads, M.; Hou, J.; Lee, K.M. Understanding the Acceptance of Teleconferencing Systems among Employees: An Extension of the Technology Acceptance Model. Comput. Hum. Behav. 2014, 39, 118-127. [CrossRef]

56. Ducey, A.J.; Coovert, M.D. Predicting Tablet Computer Use: An Extended Technology Acceptance Model for Physicians. Health Policy Technol. 2016, 5, 268-284. [CrossRef]

57. Ajzen, I.; Gilbert Cote, N.G. Attitudes and the Prediction of Behavior. In Attitudes and Attitude Change; Crano, W.D., Prislin, R., Eds.; Psychology Press: New York, NY, USA, 2008; pp. 289-311.

58. Venkatesh, V.; Davis, F.D. A Theoretical Extension of the Technology Acceptance Model: Four Longitudinal Field Studies. Manag. Sci. 2000, 46, 186-204. [CrossRef]

59. Davis, F.D.; Bagozzi, R.P.; Warshaw, P.R. User Acceptance of Computer Technology: A Comparison of Two Theoretical Models. Manag. Sci. 1989, 35, 982-1003. [CrossRef] 
60. Akram, U.; Fülöp, M.T.; Tiron-Tudor, A.; Topor, D.I.; Căpușneanu, S. Impact of Digitalization on Customers' Well-Being in the Pandemic Period: Challenges and Opportunities for the Retail Industry. Int. J. Environ. Res. Public Health 2021, 18, 7533. [CrossRef] [PubMed]

61. Davis, F.D. User Acceptance of Information Technology: System Characteristics, User Perceptions and Behavioral Impacts. Int. J. Man-Mach. Stud. 1993, 38, 475-487. [CrossRef]

62. Bandara, U.C.; Amarasena, T.S.M. Impact of Relative Advantage, Perceived Behavioural Control and Perceived Ease of Use on Intention to Adopt with Solar Energy Technology in Sri Lanka. In Proceedings of the 2018 International Conference and Utility Exhibition on Green Energy for Sustainable Development (ICUE), Phuket, Thailand, 24-26 October 2018.

63. Verma, S.; Bhattacharyya, S.S.; Kumar, S. An Extension of the Technology Acceptance Model in the Big Data Analytics System Implementation Environment. Inf. Process. Manag. 2018, 54, 791-806. [CrossRef]

64. Fishbein, M.; Ajzen, I. Belief, Attitude, Intention, and Behavior: An Introduction to Theory and Research; Addison-Wesley: Reading, MA, USA, 1975.

65. Adnan, N.; Nordin, S.M.; bin Abu Bakar, Z. Understanding and Facilitating Sustainable Agricultural Practice: A Comprehensive Analysis of Adoption Behaviour among Malaysian Paddy Farmers. Land Use Policy 2017, 68, 372-382. [CrossRef]

66. King, W.R.; He, J. A Meta-Analysis of the Technology Acceptance Model. Inf. Manag. 2006, 43, 740-755. [CrossRef]

67. Akter, M.S.; D'Ambra, J.G.; Ray, P.K. An Evaluation of PLS Based Complex Models: The Roles of Power Analysis, Predictive Relevance, and GoF Index. In Proceedings of the The Seventeenth Americas Conference on Information Systems (AMCIS 2011), Detroit, MI, USA, 4-8 August 2011; Association for Information Systems: Atlanta, GA, USA, 2011; pp. 1-7.

68. Hair, J.F.; Hult, G.T.M.; Ringle, C.M.; Sarstedt, M. A Primer on Partial Least Squares Structural Equation Modeling (PLS-SEM); Sage: Thousand Oaks, CA, USA, 2014.

69. Cohen, J.B. Exploring Attitude Construct Validity: Or Are We? Adv. Consum. Res. 1979, 6, 303-306.

70. Vogt, W.P. Quantitative Research Methods for Professionals; Pearson: New York, NY, USA, 2007.

71. Dijkstra, T.K.; Henseler, J. Consistent Partial Least Squares Path Modeling. MIS Q. 2015, 39, 297-316. [CrossRef]

72. Fornell, C.; Larcker, D.F. Evaluating Structural Equation Models with Unobservable Variables and Measurement Error. J. Mark. Res. 1981, 18, 39-50. [CrossRef]

73. Ab Hamid, M.R.; Sami, W.; Mohmad Sidek, M.H. Discriminant Validity Assessment: Use of Fornell \& Larcker Criterion versus HTMT Criterion. J. Phys. Conf. Ser. 2017, 890, 012163. [CrossRef]

74. Henseler, J.; Ringle, C.M.; Sarstedt, M. A New Criterion for Assessing Discriminant Validity in Variance-Based Structural Equation Modeling. J. Acad. Mark. Sci. 2015, 43, 115-135. [CrossRef]

75. Venkatesh, V.; James, Y.L.T.; Xu, X. Consumer Acceptance and Use of Information Technology: Extending the Unified Theory of Acceptance and Use of Technology. MIS Q. 2012, 36, 157-178. [CrossRef]

76. Byrne, B.M. Structural Equation Modeling with AMOS; Routledge: New York, NY, USA, 2010.

77. Cohen, J. Statistical Power Analysis for the Behavioral Sciences; Lawrence Erlbaum: Hillsdale, NJ, USA, 1988.

78. Cohen, J. A Power Primer. Psychol. Bull. 1992, 112, 115. [CrossRef]

79. Fornell, C.; Cha, J. Partial Least Squares (PLS); Unpublished work; 1993.

80. Chin, W.W. How to Write Up and Report PLS Analyses. In Handbook of Partial Least Squares; Springer: Berlin/Heidelberg, Germany, 2010.

81. Hussein, Z. Leading to Intention: The Role of Attitude in Relation to Technology Acceptance Model in E-Learning. Procedia Comput. Sci. 2017, 105, 159-164. [CrossRef]

82. Rezaei, R.; Ghofranfarid, M. Rural Households' Renewable Energy Usage Intention in Iran: Extending the Unified Theory of Acceptance and Use of Technology. Renew. Energy 2018, 122, 382-391. [CrossRef]

83. Cheung, R.; Vogel, D. Predicting User Acceptance of Collaborative Technologies: An Extension of the Technology Acceptance Model for e-Learning. Comput. Educ. 2013, 63, 160-175. [CrossRef]

84. Gefen, D.; Straub, D. The Relative Importance of Perceived Ease of Use in IS Adoption: A Study of E-Commerce Adoption. J. Assoc. Inf. Syst. 2000, 1, 8. [CrossRef]

85. Khazaei Pool, J.; Kazemi, R.V.; Amani, M.; Lashaki, J.K. An Extension of the Technology Acceptance Model for the E-Repurchasing of Sports Match Tickets. Int. J. Bus. Manag. Res. 2006, 6, 1-12.

86. Gangwar, H.; Date, H.; Ramaswamy, R. Understanding Determinants of Cloud Computing Adoption Using an Integrated TAM-TOE Model. J. Enterp. Inf. Manag. 2015, 28, 107-130. [CrossRef]

87. Teo, T. Modelling Technology Acceptance in Education: A Study of Pre-Service Teachers. Comput. Educ. 2009, 52, 302-312. [CrossRef]

88. Yi, M.Y.; Jackson, J.D.; Park, J.S.; Probst, J.C. Understanding Information Technology Acceptance by Individual Professionals: Toward an Integrative View. Inf. Manag. 2006, 43, 350-363. [CrossRef]

89. Lee, Y.-H.; Hsiao, C.; Purnomo, S.H. An Empirical Examination of Individual and System Characteristics on Enhancing E-Learning Acceptance. Australas. J. Educ. Technol. 2014, 30, 562-579. [CrossRef]

90. Karaoğlan, S.; Durukan, T. Effect of Environmental Awareness on Willingness to Pay for Renewable Energy. Int. J. Bus. Manag. Invent. 2016, 5, 42-48.

91. Karasmanaki, E.; Tsantopoulos, G. Exploring Future Scientists' Awareness about and Attitudes towards Renewable Energy Sources. Energy Policy 2019, 131, 111-119. [CrossRef] 